The question of the estimation of the crosslinking of polymer chains is still an outstanding problem in this branch of the subject, as the method hitherto available for computing branching in ordinary explosive chain reactions is not applicable in the present instance.

\section{REFERENOES}

1 Discussion on Kinetics, Trans. Faraday Soc., 34, 1 (1938).

2 Melville and Bolland, Proc. Roy. Soc., A, 160, 384 (1937).

3 Farkas, L. and A., and Rideal, Proc. Roy. Soc., A, 146, 630 (1934).

- Morikawa, Benedict and Taylor, J. Amer. Chem. Soc., 58, 1445 (1936).

s For a summary see Melville, Science Progress, No. 123, 499 (1937).

- Evans and Polanyi, Trans. Faraday Soc., 34, 11 (1938).

'Melville, Proc. Roy. Soc., A, 163, 511 (1937).

\title{
The Spring Drought in the British Isles
}

\section{By E. G. Bilham}

$\mathrm{T}$ HE spring of 1938 has been rendered memorable in the British Isles by a remarkable sequence of meteorological events, the results of which have been disastrous to the horticultural and farming sections of the community. The main purpose of this article is to furnish data in regard to the drought, but it is important to realize that the deficiency of rain, unprecedented as it has been, is only one aspect of a singularly unfavourable meteorological complex. Thus the fruit growers would probably have made little complaint about the drought if they had been spared the frosts of April and early May, following upon an exceptionally mild March in which all vegetation made rapid growth. Incidentally, March and April have provided an example of the untrustworthiness of the generalization that the rainfall of the British Isles is related to the direction of the prevailing wind ; in March we had a great shortage of rainfall and the winds were persistently south-westerly ; in April we also had a very dry month and the winds were persistently north-easterly.

The period of exceptional rainfall deficiency began in February, following upon a wet January. In February pressure exceeded the normal by about ten millibars in all parts of the British Isles, and as is usual when anticyclonic conditions predominate, rainfall was markedly below normal, though there was an excess in the west and northwest of Scotland, and in small areas in Yorkshire and south-west Ireland. At Kew Observatory the total fall for the month was only 0.31 inch, or 20 per cent of the normal. The general fall over England and Wales, deduced from the observations at a selection of representative stations, was 1.34 inches, or 52 per cent of the normal. For Scotland, the percentage was 80 , for Ireland 66 , and for the British Isles as a whole, 62 .

The corresponding values for March and April, and for the whole period February to April, are included in the accompanying table. It will be seen that March was very decidedly drier than February in England and Wales, though Scotland had nearly the normal rainfall. The drought was particularly severe in the western Midlands, and at Ross-on-Wye the total for the month was no more than 0.02 inch, the smallest total for March in records going back to 1859 . On the other hand, exceptionally heavy rains occurred in parts of western Scotland. At Loan (Loch Quoich), in Inverness-shire, the total for March was no less than 50.03 inches, one of the largest monthly totals ever recorded anywhere in the British Isles.

General RaINFall of the BRITISH ISIES, FEbrUary to APRIL, 1938

\begin{tabular}{|c|c|c|c|c|}
\hline & $\begin{array}{c}\text { England } \\
\text { and Wales }\end{array}$ & Scotland & Ireland & $\underset{\text { Isles }}{\text { British }}$ \\
\hline $\begin{array}{l}\text { February } \\
\text { Per cent of normal }\end{array}$ & $\begin{array}{c}1 \cdot 34 \mathrm{in} \\
52\end{array}$ & $\begin{array}{c}3 \cdot 34 \text { in. } \\
80\end{array}$ & $\begin{array}{c}2 \cdot 33 \text { in. } \\
66\end{array}$ & $\underset{62}{2 \cdot 02}$ in. \\
\hline $\begin{array}{l}\text { March } \\
\text { Per cent of normal }\end{array}$ & $\underset{27}{0.72}$ in. & $\begin{array}{l}3.93 \text { in. } \\
97\end{array}$ & $\underset{65}{2 \cdot 18}$ in. & $\begin{array}{c}1.67 \mathrm{in} . \\
52\end{array}$ \\
\hline $\begin{array}{l}\text { April } \\
\text { Per cent of normal }\end{array}$ & $\underset{13}{0.28 \text { in. }}$ & $\underset{34}{1 \cdot 02}$ in. & $\frac{0 \cdot 20}{7}$ in. & $\begin{array}{c}0.43 \\
17\end{array}$ in. \\
\hline $\begin{array}{l}\text { Total } \\
\text { Per cent of normal }\end{array}$ & $\begin{array}{c}2 \cdot 34 \text { in } \\
32\end{array}$ & $\underset{74}{8 \cdot 29}$ in. & $\underset{49}{4 \cdot 71 \text { in }}$ & $4 \cdot \frac{12}{45}$ in. \\
\hline
\end{tabular}

Although the total fall for February and March was exceptionally small in many areas, the drought had not achieved a record-breaking character at that stage. For England and Wales, the general fall in the two months was 2.06 inches, and we only have to go back ten years to 1929 to find a substantially smaller fall, $1.60 \mathrm{inch}$, in the same two months. April, however, brought a very great and general intensification of the shortage. With a general fall of no more than 0.43 inch over the British Isles as a whole, it was not only the driest April in our annals, but also the driest month of any name of which we possess records. The general rainfall was, however, only slightly exceeded in February 1891, June 1925 and February 1932.

For England and Wales the percentage of normal was 13. So far as our information goes, only three previous Aprils have yielded percentages less than twenty; namely, those of 1817 (16 per cent), 1893 (18 per cent) and 1912 (15 per cent). April 1893 was remarkable for having yielded no rainfall at all over a large area in south-east England. April 1938 achieved that distinction at 
only a few stations; the main feature was the widespread distribution of the drought. The tery small percentage of normal, 7 , in Ireland is particularly striking. No previous April has produced anything like such a deficiency in that area.

The total rainfall of the three months February to April 1938 amounted in England and Wales to 2.34 inches, or 32 per cent of the normal. No previous combination of three successive months has yielded so small a total since comparable evaluations began in the year 1870. It is possible to carry the comparison back for more than another century, with some approach to certainty, by referring to a series of estimates of general rainfall percentages by Dr. J. Glasspoole and Miss F. J. Nicholas published in British Rainfall, 1931. From these estimates it appears that a comparable period occurred in 1785, when the combined total for February to April amounted to about 2.1 inches. No more recent sequence of three months has been drier than that experienced this year.
To the natural question "why?", we can only reply at the moment that the dry weather was due to an exceptional persistence of anticyclonic conditions, combined in April with a prevalence of north-easterly winds. At the present stage of our knowledge of the causes of seasonal weather changes, the reasons for such persistence cannot be clearly made out; still less can they be foreseen. It has long been realized that the investigation of such problems demands a study of meteorology on a world-wide scale, and we may recall that the exceptional summer of 1911 provided the initial incentive which led to the regular publication of the collection of world weather statistics known by the name of the Reseau Mondial. If the harvest has not yet been garnered, we may, however, derive some satisfaction from the fact that there are many workers in the field, and also from the fact that some degree of success has rewarded the essays in 'seasonal foreshadowing' made in India and elsewhere.

\section{Obituary Notices}

\section{Mr. J. E. Marsh, F.R.S.*}

$\mathrm{T}$ HE numerous friends and old students of James Ernest Marsh will have learned with regret of his death on April 13 at the age of seventy-seven years. He was one of the few remaining ehemists whose most active period of work belongs to last century, having been University demonstrator in chemistry at Oxford from 1886. In my undergraduate days, 1896-98, Marsh in organic chemistry and V. H. Veley, who died at just the same age in 1933, in inorganic chemistry, were almost the only ones in Oxford keeping the flag flying as regards original work in the subject.

Marsh's influence on me started, indeed, at school, under R. E. Hughes, science master at Eastbourne College, who, whilst at Jesus College, had worked with Marsh, and was still being provided by him with materials and help in its continuation. Few schoolboys certainly can have prepared camphoryl chloride. But I still have a vivid recollection of carrying out this preparation on a large scale in the open playing field, adjoining the school laboratory, from camphoric acid and phosphorus pentachloride, and of the traditional 'torrents' of hydrochloric acid gas evolved. That, to a schoolboy, was the joyous beginning of a lifetime admiration.

At that time Marsh was deeply immersed in the study of camphor and the related group of terpenes. The problem of the constitution and synthesis of camphor was then very much to the fore, and some of the most eminent chemists, including the late

\footnotetext{
* Reprinted by permission of the editor, from the Oxford Magazine.
}

Prof. W. H. Perkin, were engaged on it. In conjunction with his students, notably J. A. Gardner and A. Hartridge, Marsh published about twenty important papers in this field between 1889 and 1910 , in the first of which he had suggested for camphor a highly original structural formula. Although this was ultimately disproved in favour of one propounded by Bredt in 1893, he made, in the course of the work, many interesting and important discoveries. The stereochemistry of this group led to great advances in our knowledge of that subject, and Marsh himself was the first to obtain, for the case of camphoric acid, optically active stereo-isomers of the cis and trans variety associated with the ring structure.

At this time Marsh was an acknowledged leading authority in the field of stereochemistry, and his lectures on the subject, drawing his illustrations and examples from this field, and many others such as the sugars, then undergoing intensive study, were most inspiring and threw an interesting light over the whole field of organic chemistry. Another topic on which he used to lecture regularly was the history of chemistry. In 1929 he collected in a book entitled "The Origins and the Growth of Chemical Science" his main conclusions, the chief of which was that the earlier work on salt formation and the fixation of gases by the British chemists, Boyle and Black, were the real beginning of the subject as a science rather than the later work of Lavoisier on combustion to which it is often ascribed.

In later years, largely with R. de J. F. Struthers, Marsh worked much on the numerous curious and interesting complexes formed by certain compounds 